\title{
Difficulties Regarding the Right to Be Forgotten in the Case Law of the Strasbourg Court
}

\author{
By Veronika Szeghalmi*
}

\begin{abstract}
Through the interpretation of the European Convention on Human Rights, the case law of the European Court of Human Rights plays a central role in developing the case law of other European courts, and its guidance is of utmost importance for European states that seek to follow certain European minimum principles. While its case law is evolving continuously, the court seems unable to keep up with the pace of changes brought about developments in digital technology and the spread of the Internet. Thus, the principles developed by the court for the offline world need to be revised, even though the role and impact of the court on European legal theory is met by no other institution. Such phenomena may break down the foundations of our traditional theoretical frameworks and lead to the necessity to revisit the balancing principles applied when there is a conflict between individual rights. With regard to the 'right to be forgotten' introduced by the Court of Justice of the European Union in its Google Spain Judgement, this paper seeks to identify certain challenges the balancing standard applied concerning Articles 8 and 10 of European Convention of Human Rights may need to face in the future.
\end{abstract}

Keywords: Right to Privacy; Right to be Forgotten; Freedom of Expression; GDPR; Court of Justice of the European Union; European Court of Human Rights; European Convention on Human Rights.

\section{Introduction and Methodology}

In 2010, Mario Costeja González realised that information displayed on the list of search results returned by Google's search engine included a link to a newspaper article published in the online edition of La Vanguardia, a Catalan daily paper, which contained outdated information regarding Mr. González. The newspaper article contained information on an official proceeding relating to the collection of Mr. González's public debt. However, the content of the article was outdated at the time of running the search, as the cases were settled in the meantime. The case made its way through the Spanish authorities to the Court of Justice of the European Union (hereinafter "CJEU") and became commonly known as the Google Spain ${ }^{1}$ case, in which the CJEU held that Mr. González had a right to be forgotten by the Internet. In the wake of the judgement passed in Google Spain, Article 17 of the EU General Data Protection Regulation also

\footnotetext{
${ }^{*} \mathrm{PhD}$ Student and Visiting Lecturer, University of Szeged, Faculty of Law and Political Science, Szeged, Hungary. Media specialist, Institute for Media Studies of the NMIA, Budapest, Hungary. Email: szeghalmi.veronika@gmail.com.

${ }^{1}$ Google Spain SL, Google Inc. v Agencia Española de Protección de Datos, Mario Costeja González (2014) (hereinafter Google Spain).
} 
provides for a right to be forgotten and lays down the conditions of exercising that right. ${ }^{2}$ This right serves as a guarantee that users may request Google or other search engine providers to erase links to information that may be associated with them, provided that certain conditions are met. ${ }^{3}$ According to the CJEU, this right is based on the provisions of the Data Protection Directive and Articles 7 and 8 of the EU Charter of Fundamental Rights providing protection for private life and personal data, respectively. The interpretation of these provisions is also supported by the interpretation of the European Convention on Human Rights (hereinafter "ECHR") as rendered by the established by the case law of the European Court of Human Rights (hereinafter "ECtHR").

After clarifying certain preliminary issues, this paper attempts to highlight the importance of various matters that have been covered only indirectly by the case law of the court so far. This study makes an attempt to compare the reasons for a right to be forgotten, as presented in the Google Spain judgement, to the guidelines developed by the ECtHR, with a strong focus on the role of freedom of expression when balanced against the right to be forgotten forming part of the right to private life. In other words, this paper examines the relationship between Article $8 \mathrm{ECHR}$ and the right to be forgotten, and considers the challenges faced by the balancing standard traditionally applied in the case law of the ECtHR when interpreting/re-interpreting the right to be forgotten.

\section{The Relevance of the Right to be Forgotten under the European Convention on Human Rights}

According to Article 10 of ECHR, every person has a right to freedom of expression, and this right includes the freedom to hold opinions and to receive and impart information and ideas. ${ }^{4}$ However, the right mentioned in this provision does not exist in a vacuum ${ }^{5}$, and it may be limited on the ground of protecting the rights of others. For example, the right of others to a private life may be a reasonable limit of the right provided for in Article 10. This means that if the right to be forgotten is derived from the right to a private life provided for in Article $8 \mathrm{ECHR}$, then the right to access information, as provided for in Article

\footnotetext{
${ }^{2}$ REGULATION (EU) 2016/679. The EU General Data Protection Regulation (“GDPR”) entered into force on 24 May 2016 and has been mandatorily and directly applicable without any further legal act by the Member States. According to Article 17 of the Regulation, a data subject has the right to obtain from the controller the erasure of personal data concerning him or her and a controller has the obligation to erase personal data where any of the grounds specified in Articles 17(1)(a) to (f) applies. Where a controller has made the personal data public and is obliged to erase the personal data on any of the above grounds, the controller, taking account of available technology and the cost of implementation, is to take reasonable steps to inform controllers which are processing the personal data that the data subject has requested the erasure by such controllers of any links to, or copy or replication of, those personal data. The provision is not applicable where the processing of data is necessary for any of the reasons specified in points (a) to (e) of paragraph (3), including for exercising the right of freedom of expression.

${ }^{3}$ Keller (2014).

${ }^{4}$ Leander v. Sweden (1987).

${ }^{5}$ Dulong de Rosnay \& Guadamuz (2016).
} 
10, may be limited on the ground of protecting the right to be forgotten, provided that certain conditions are met. This issue is considered by the court on an ad hoc basis by balancing the rights provided for in Articles 8 and 10. Various eras of this balancing process can be identified in the case law of the court. ${ }^{6}$ As part of its progressive legal activities, the court applies various principles of interpretation. For the purpose of the right to be forgotten, the doctrine of a living instrument seems relevant, as it allows the court to interpret the provisions of the Convention as living law and to compare and adjust its changes to the current situation and circumstances. This doctrine may enable the ECtHR to acknowledge a new interpretation of the right to be forgotten; the existence of this right has already been acknowledged in the case law of the court, but its components need further clarification, considering that the nature of the flow of information on the Internet might make it necessary to take into account various factors that were not taken into account in the case law pertaining to the offline world. In an online environment, the right to be forgotten is not limited to the possibility to have some information "erased", but it also restricts the activities of search engines by "cutting" the link shown among the search results of such engines; in other words, it does not erase the piece of information concerned, merely makes it inaccessible, provided that the conditions of exercising the right to be forgotten are met.

At the time of writing, there is no information available on such an interpretation of the right to be forgotten by the ECtHR with regard to Google. However, to make future applications concerning the right to be forgotten relevant under Article 8 of the Convention, it must be considered how a case involving Google may be brought before the ECtHR, and how the right to be forgotten may be rooted in the case law of the court.

Primarily, a claim may be based on a violation of the Convention, if the applicant, after exhausting the available effective remedies under national law, files a motion against a member state; this means that the subject of the dispute is not the establishment of liability on the side of a private party. ${ }^{7}$ Thus, the violation of a right provided for in the Convention may be established, if the violations of the rights of an individual provided for under the Convention are committed by a member state. ${ }^{8}$ However, the case law of the court recognises the possibility of holding a member state accountable for the actions of a private party. ${ }^{9}$ Following the arguments of Simon Wechsler, such accountability may be established if a state fails to perform its positive obligation to take adequate measures to ensure that Google and other search engine providers operate in a lawful manner, and, by not establishing an appropriate legal framework or applying the existing rules inadequately, it allows such service providers to misinterpret or ignore situations where the right to be forgotten may be exercised. Another, somewhat questionable, argument is that the right to be forgotten may be relevant to the ECtHR, if the activities of Google and other search engine

\footnotetext{
${ }^{6}$ Keller (2014) at 395.

${ }^{7}$ Wechlsler (2015).

${ }^{8}$ Convention for the Protection of Human Rights and Fundamental Freedoms (1950).

${ }^{9}$ Palomo Sanchez and Others v. Spain (2011).
} 
providers are considered the performance of government tasks, and the case is brought to the ECtHR because Google itself may be considered a government actor that is capable of violating the rights of individuals, thereby making it possible to bring the case to the court. However, this does not seem feasible without recognizing that Google and other search engine providers carry out a task delegated onto them by the state when they decide on granting or denying a request for erasure, i.e. on the possibility of exercising the right to be forgotten. ${ }^{10}$ In light of the above considerations, it seems possible that a future situation may arise where the ECtHR will have to address the notion of the right to be forgotten in an online environment.

However, when considering the relevance of the right to be forgotten for the purpose of the ECHR, it should be pointed out that the grounds the CJEU relied on in the Google Spain decision are different from the grounds the ECtHR relied on when it elaborated the meaning of the right to a private life in its case law. On the one hand, the CJEU considered primarily the purpose limitation of data processing in light of Articles 7 and 8 of the Charter of Fundamental Rights and the provisions laid down in the Data Protection Directive, and it assessed whether the data processing by Google is excessive, irrelevant, or outdated with regard to the original purposes of processing. On such grounds the CJEU ruled that, among others, making the links to the personal data of the Spanish applicant available was unlawful, and it ordered Google to make the links to such data unavailable. On the other hand, the ECtHR attempted to balance access to information about individuals against the rights of the individual concerned with general effect, and it sought determine if the individual concerned suffered any damages due to the publication of information. ${ }^{11}$

The remaining questions include to what extent can the ECtHR follow the directions of interpretation specified laid down in the Google Spain decision in the course of applying the traditional balancing standard, and what changes will this standard undergo with regard to the new problems that arise concerning online surfaces and the operation of search engines. Another question is whether or not the ECtHR needs to apply additional conditions to be able to strike an adequate balance between Articles 8 and 10 ECHR. Moreover, it might become necessary to extend the scope of the right to private life in order to enable the court to assess the application of the right to be forgotten. The ECtHR has already faced difficulties concerning the interpretation of Article 8 ECHR on numerous occasions. As already noted, the ECtHR brought more and more rights under the scope of Article 8 of ECHR by applying the living instrument doctrine; among others, the right to the protection of personal data was developed into an individual right recognised under Article 8 of ECHR. ${ }^{12}$ Today, the ECtHR enables individuals to flourish by gradually recognizing various personality

\footnotetext{
${ }^{10}$ However, this position seems questionable. Even though it seems clear that Google, by creating a public space, has become an important component of the operation of democratic societies, the government still provides additional legal remedies, should Google fail to guarantee the possibility of exercising the right to be forgotten. For this reason, the idea of Google carrying out government tasks is quite doubtful.

${ }^{11}$ Post (2017).

${ }^{12}$ Sloot (2018) at 39.
} 
rights or, in the words of Feinberg,"interests leading to human flourishing". ${ }^{13}$ As a result of recent efforts taken by the ECtHR, the right to private life provided for under Article 8 of ECHR has been transformed into a conventional personality right. ${ }^{14}$ Recently, the rights recognised under Article 8 of ECHR have exceeded the traditional aspects of the right to private life due to the interpretation activity of the ECtHR, and it has become known as the right human flourishing in recent legal literature. In the context of the expanding scope of Article 8 of ECHR, the dissenting opinion of Judge Egidijus Küris to a recent case should be mentioned, as it points out the limitations of interpretation regarding Article 8 of ECHR. With regard to the meaning of the right to a private life provided for under Article 8, Judge Küris notes that it is a noticeable trend in the case law of the ECtHR that, in light of the broad limits of interpreting the meaning of the right to a private life, whatever is not excluded in principle is considered by the ECtHR as the rule automatically and as an interference with private life. A possible issue with this approach is that the meaning of private life has been expanded by the ECtHR so far that it covers almost each and every kind of activities, including activities that belong to the private sector by nature and are only loosely connected to private life. However, Judge Küris also notes that another trend is also noticeable in the ECtHR case law. Namely, certain judgements seem to "ignore" the personality rights effectively protected under Article 8 of ECHR in order to guarantee the right to the freedom of expression provided for under Article 10 of ECHR. ${ }^{15}$ This seems to suggest that, on the one hand, the case law of the ECtHR is inconsistent, and, on the other hand, the application of the right to private life in contemporary cases might be hindered by interpretation-related limitations in the future, when the recognition of such rights in an online environment is elaborated in more detail. ${ }^{16}$ It follows from the above considerations that the right to a private life needs to be re-interpreted in light of the right to be forgotten, and its relationship with Article 10 ECHR needs to be revisited. This way, applications for erasure from an offline database will be considered differently from applications for "being forgotten" among the search results of a search engine that provides fundamental access to information. Granting such requests without carefully elaborated standards might hinder the everyday flow of information, but may also become a means of protecting the personality of individuals. In light of the guidelines emerging from the case law, it seems that the court is of the opinion that exercising the rights of individuals in such a manner might be construed as the rewriting of history. ${ }^{17}$ This means that the ECtHR must reconsider the criteria of balancing that were applied earlier when the court decided on recognizing the right to be forgotten. Nonetheless, the limitations of expression, which were developed by the court

\footnotetext{
${ }^{13}$ Feinberg (1984) at 37.

${ }^{14}$ Sloot (2018) at 39.

${ }^{15}$ Dissenting opinion by Judge Küris in Erményi v. Hungary (2016). The European Court of Human Rights (ECtHR) ruled against Hungary and held that the Hungarian authorities violated the right to a private life of Erményi, Lajos, former vice-president of the Supreme Court, by removing him from his position by law before his time.

${ }^{16}$ Perez \& Baldia (2011).

${ }^{17}$ Węgrzynowski and Smolczewski v. Poland Application (2013).
} 
mostly with regard to an offline environment, should not be thrown out altogether as they may also be applied in an online environment. ${ }^{18}$ The following paragraphs make an attempt to demonstrate the various challenges faced by the traditional means of interpretation applied by the court.

\section{Various Approaches to the Interpretation of the Right to be Forgotten Google Spain Judgement "v." Strasbourg Case Law}

The reasons of the Google Spain decision and the explanation for the theoretical framework of the right to be forgotten are rooted in the provisions laid down in the Data Protection Directive and Articles 7 and 8 of the EU Charter of Fundamental Rights. Article 8 of the Charter provides that everyone has the right to the protection of personal data concerning him or her, that such data must be processed fairly for specified purposes and on the basis of the consent of the person concerned or some other legitimate basis laid down by law, and that everyone has the right of access to data which has been collected concerning him or her, and the right to have it rectified. Article 7 provides that everyone has the right to respect for his or her private and family life, home and communications. This Article is in fact a repetition of Article 8 of ECHR providing for the right to respect for private and family life, meaning that the right provided for under Article 7 of the EU Charter should be interpreted the same way as Article 8 is interpreted by the ECtHR. Furthermore, this connection is also established by Article 52(3) of the EU Charter, providing that in so far as the EU Charter contains rights which correspond to rights guaranteed by the ECHR, the meaning and scope of those rights are to be the same as those laid down by the said Convention. However, following the ideas of Robert Post, the ECtHR lays down a theoretical framework for the right to be forgotten that is different from the one presented in the directive serving as ground for the Google Spain decision, Article 8 of the EU Charter of Fundamental Rights, or the EU GDPR (mandatorily applicable as of May 2018). The ECtHR case law focuses on guaranteeing a balance between the right to public debate and the damages caused by publication. In this context, the court applies the serious harm standard to assess the damages, meaning that the damages caused must reach a certain level to become a relevant factor concerning the violation of the right to private life. With regard to the right to be forgotten, the court will have to consider whether or not the damage (serious harm) was caused by the search results. In Tamiz v. $U K^{19}$ the court ruled that Google's blog-publishing service was not liable for comments, because the damages caused by such comments did not exceed the level of trivial effect. In other words, the ECtHR ruled that the damages were not significant in that case. ${ }^{20}$ In multiple cases, the court took into consideration the number of individuals who had access to a given piece of content when assessing the level of damages caused by a piece of communication.

\footnotetext{
${ }^{18}$ Koltay (2017) at 133.

${ }^{19}$ Tamiz v UK (2017).

${ }^{20}$ Reputation is protected by the ECtHR under Article 8 ECHR.
} 
For example, the ECtHR held in Einarson v. Iceland that the publication of a photograph on Instagram violated the right to respect for private life because the communication, being published on a public website, may reach a high number of people. ${ }^{21}$

However, the pieces of legislation serving as ground for the Google Spain decision (the Directive, Article 8 of the EU Charter of Fundamental Rights, and the GDPR) apply a fundamentally different approach to the right to be forgotten. For example, the damages caused to the individual concerned are not mentioned in the Google Spain decision; on the contrary, it is specifically noted in the decision that the violation of his or her rights may be established even if the individual concerned did not suffer any damage. The CJEU explains in its reasoning that, with regard to "forgetting" a piece of information, it should be examined if the processing of the data concerned became irrelevant or excessive as compared to the purpose of processing. ${ }^{22}$ In a sense, it is not easy to determine the meaning of terms like irrelevant, outdated, or excessive compared to the purpose of processing with regard to a link published by Google to a given website. Furthermore, as Post argues, such instrumental provisions and reasons seek to ensure the application of fair information processing practices, and extend such practices to Google, while they fails to acknowledge that Google, even though it is not a press outlet in the traditional sense of the word, can be considered as to have the same status as any other member of the press, and as such, the application of such instrumental provisions seem to be inapplicable. The press is to ensure the democratic operation of the public sphere, and it seems clear that Google performs the very same function by providing various links. For this reason, the instrumental provisions laid down in Article 8 of the EU Charter are quite hard to apply to the operations of Google. Thus, Post argues that the message of the Google Spain decision is fundamentally vague, as it refers to the instrumental provisions laid down in Article 8 of the EU Charter, which seeks to establish the above-mentioned fair information processing practices regarding platforms like Google - but such platforms necessitate a different approach due to their role. ${ }^{23}$ Altogether, the CJEU considers Google an economic operator, and does not place adequate emphasis on the role it plays in society. This approach is also challenged by Daniel J Solove, a distinguished academic and privacy researcher, who analysed the issue whether or not Google may be considered a business association that is controlled by financial goals exclusively, ignoring the non-economic role it plays in contemporary societies. ${ }^{24}$ However, the decision also invokes Article 7 of the EU Charter of Fundamental Rights, which does not seek to guarantee the right to dispose of data, but serves as a guarantee for human dignity, as elaborated in more detail in the case law of the ECtHR. Article 7 of the EU Charter may provide a more efficient means of reinterpreting the meaning, and ensuring the protection, of a public sphere by Google, than the provision laid down in Article 8 of the EU Charter, as the

\footnotetext{
${ }^{21}$ Einarsson v. Iceland (2017).

${ }^{22}$ Google Spain at 94.

${ }^{23}$ Post (2017) at 712 .

${ }^{24}$ Solove (2014).
} 
administrative logic of the latter is fundamentally incompatible with the communications related actions expected by a democratic public sphere. Data processing of this type may make sense in the context of large data sets collected and processed by governments or commercial bureaucracies. ${ }^{25}$ Google needs to be handled differently, because it is a fundamental source for the public; if the logic of instrumental administration is to be followed and a person is to be given control over his or her data, such control would hinder the exchange of information even in the context of matters that are subject to public debate continuously. Such an approach is fundamentally different from the one taken by the ECtHR, as it applies the right to be forgotten mostly as a means of consolidating the values of public discourse and private life. In this sense, the ECtHR focuses on the issue whether or not individual pieces of communication might become so harmful under the norms of "public morality" that they do not serve the legitimate interests of public opinion any longer and may be forgotten. ${ }^{26}$ This approach was affirmed by the ECtHR in Couderc and Hachette Filipachi Associesies $v$ France, where the court explained that the right provided for under Article 8 of the Convention is to be construed in light of the "external context". ${ }^{27}$ It may be concluded from the above considerations that the approach taken by the ECtHR toward the right to be forgotten follows a logic that is fundamentally different that of the right to be forgotten as elaborated in the Google Spain decision. The right to be forgotten as elaborated in that decision is not easy to consolidate with the value of social discourse, as individuals normally engage in discourse without determining the purpose of the discourse in advance, meaning that the assessment of purpose limitation is pointless in most common situations. However, the approach taken by the ECtHR toward the right to be forgotten is incompatible with and restricts the idea of public discourse. First, it restricts the idea of public discourse, because it prevents the publication of outdated information that violates human dignity and it allows individuals to have such information forgotten; second, it is incompatible with that idea, because it allows individuals to engage in public discourse without determining the purpose of the discourse in advance, and, by doing so, it seeks to strike a balance between public discourse and human dignity. This means that the interpretation provided by the ECtHR is more closely related to Article 7 of the EU Charter, which allows for a more flexible interpretation, because that provision may be able to guarantee the protection of human dignity by balancing the respective rights concerned. This was also noted by the court in the Google Spain decision, but the provisions laid down in Article 8 of the EU Charter prevailed over the provisions of Article 7 that are more closely related to the protection of human dignity. ${ }^{28}$ The CJEU sought to loosen up this instrumental logic by acknowledging in the Google Spain decision that the public role of an individual may justify the limitation of his or her personality rights, meaning that the right to be forgotten may not be applied

\footnotetext{
${ }^{25}$ Post (2017) at 718.

${ }^{26}$ Post (2017) at 724-731.

${ }^{27}$ Couderc and Hachette Filipachi Associesies v France (2015).

${ }^{28}$ Hirschleifer (1980) at 649.
} 
for public figures. ${ }^{29}$ Furthermore, both the Directive and the directly applicable GDPR provides that the use of data for journalistic purposes must be considered an exception, regardless to the content of any specific newspaper article. ${ }^{30}$

\section{The Traditional Balancing Criteria applied by the ECtHR and its Challenges}

The CJEU did not reject the possibility of applying the approach taken by the ECtHR to address the right to be forgotten, but the reasons behind its decision is affected by the interpretation related difficulties discussed above. Furthermore, there is no general consensus regarding the issue of to what extent the CJEU relied on the traditional balancing standard elaborated by the ECtHR. For example, Article 19, a watchdog organisation, expressed concerns because the CJEU failed to carry out an adequate balancing of rights, and its decision imposes considerable restriction on the freedom of expression to serve the interests of the right to a private life. $^{31}$

This balancing standard seeks to strike a fair balance, requiring the courts of member states to set a fair balance between the rights provided for under the ECHR. ${ }^{32}$ The ECtHR relies on the criteria specified in the Von Hannover (No.2) decision in the course of setting a balance between Articles 8 and 10 ECHR. According to the set of criteria elaborated in this case, the court considers to what extent a piece of communication contributes to the debate of general interest, the notoriety of the person concerned and the relationship to the press, the prior conduct of the person concerned, and the circumstances in which the material at issue was obtained. ${ }^{33}$ In the course of such balancing, it must be taken into account whether or not a person shown on a photograph agreed to the shooting and publication of the picture, and if the picture was taken without the subject's knowledge, or otherwise in a fraudulent or otherwise unlawful manner. The nature and seriousness of intruding into the private life of the subject (content and form of the publications), and the consequences of publishing the photograph for the individual concerned must also be taken into account.

However, the assessment of individual components of the standard, which was elaborated by the court with an offline environment in mind, is subject to continuous changes in the era of online communications. In a paper discussing the nature of the right to be forgotten, Gabrielle Guillemin described this situation with the phrase of old concept, new challenges. ${ }^{34}$ With regard to the first component of the standard, Guillemin argues that the interpretation of the term contribution to the debate of general interest is a product of considerable developments in the case law of the ECtHR, and its limits cannot be specified

\footnotetext{
${ }^{29}$ Google Spain at $97-99$.

${ }^{30}$ Directive 95/46/EC of the European Parliament and of the Council of 24 October 1995; GDPR at 85.

${ }^{31}$ ARTICLE 19's Response to Google's Advisory Council 16 October 2014. https://www.article19. org/data/files/medialibrary/37733/A19-comments-on-RTBF.pdf

${ }^{32}$ Barendt (2010) at 48.

${ }^{33}$ Von Hannover v. Germany (no. 2) (2012).

${ }^{34}$ Guillemin (2015) at 231.
} 
clearly. According to the decision passed in Animal Defenders Int. v. UK ${ }^{35}$, general interest information include information and data pertaining to the affairs of politicians, public health and safety, legislation, consumer and social interests, environmental protection, and other information concerning the economy, culture, or the arts. Guillemin also points out that Mosley $v . U K^{36}$ represented a turning point in the assessment of general interest information, as the ECtHR made a distinction between public interest information and information the public might be interested in. According to the ECtHR, the latter includes information that is not public interest information but can satisfy the information needs of the public. In this regard, Guillemin argues that the standards of public interest information and information the public might be interested in are to undergo fundamental changes in the era of the Internet, as the matter of what information may be considered public interest information is going to become much more complicated than ever before. Individual online posts may seem insignificant and should not be considered public interest information. However, if the path to the information contained therein is erased due to the right to be forgotten, then the piece of information concerned becomes permanently inaccessible, even if it might contribute to finding the truth about an issue. This could cause difficulties in matters where certain aspects of the matter are of public interest. ${ }^{37}$ Furthermore, the court emphasised in Times Newspapers Ltd. v. United Kingdom that, similarly to the safekeeping of traditional databases, there is a public interest in safekeeping online archives that maintain the flow of information. This consideration is known as a cultural aspect of the Internet, as it contributes to the preservation of cultural values. The court also emphasised that, in a sense, Google created a mobile archive that is identical to the Internet itself. ${ }^{38}$ Google plays an important role in granting the public access to news and spreading information. ${ }^{39}$ The position of the ECtHR is fundamentally expressed in an important guidance provided in another case, noting that the authorities are not tasked with "rewriting history" by allowing the erasure of online data. ${ }^{40}$ In light of the above, one might agree with Wechsler in that the court fundamentally took a stand on the side of the right to remember against the right to be forgotten. ${ }^{41}$

The following component of the traditional balancing standard is the assessment of notoriety and status as a public figure of the individual concerned. In Lingens $v$ Austria, the ECtHR explained that the personality rights of public figures are exposed to more significant attacks, and such individual need to carry a greater burden and have a higher level of tolerance. ${ }^{42}$ The public might be interested in the private life of public figures, and the freedom of expression provided for in Article 10 ECHR may also be exercised more freely with

\footnotetext{
${ }^{35}$ Animal Defenders Int. v. UK (2013).

${ }^{36}$ Mosley v United Kingdom [2011].

${ }^{37}$ Iglezakis (2016).

${ }^{38}$ Times Newspapers Ltd (Nos. 1 And 2) v The United Kingdom (2009).

${ }^{39}$ Magyarországi Tartalomszolgáltatók Egyesülete and Index Zrt v Hungary (2016)/

${ }^{40}$ Węgrzynowski and Smolczewski v. Poland (2013).

${ }^{41}$ Wechsler (2015).

${ }^{42}$ Lingens v Austria (1986).
} 
regard to such individuals. ${ }^{43}$ Furthermore, the court also ruled in another case that even taxation related matters can be of public interest. ${ }^{44}$ In other respects, the case law of the ECtHR suggests that information pertaining to private life may not be published, unless it is related to a public function or is otherwise of public interest. The factors mentioned in Axel Springer might serve as important guidelines in deciding on the relationship between this right and the right to private life, and on how it could be balanced against the freedom of expression. In that case, the court ruled that, in order to establish the violation of the right to private life, the infringement must reach a certain threshold of seriousness, suggesting that the communication concerned had, or is capable of having, a detrimental impact on the right to private life. Furthermore, the court also explained in its judgement the violation of the right to private life may not be invoked in a situation where the infringement was foreseeable and is rooted in the actions of the individual concerned. ${ }^{45}$ If these conditions are met, the erasure of the respective piece of information may be regarded as a means of limiting access to information. In such cases, the court needs to examine if the rights of the claimant have been violated indeed by the fact that the given pieces of information became available on the Internet, and to what extent the rights of the individual concerned would be harmed by the information remaining available online, when compared to the requirements of public interest.

The balancing standard of the ECtHR takes also into account the actions taken by the individual concerned that led to the publication of information pertaining to his or her private life. Daily activities pursued in social media might be relevant to this issue, as users consent to the processing of their data on such media surfaces. In such situations, Article 8 ECHR may not be invoked, if the individual concerned cannot show that search engines connect his or her name to various pieces of information in an unlawful manner. Since the individual concerned made information on his or her private life publicly available previously, he or she may not claim that his or her previous action did not constitute consent to making such information available. In this respect, the court considered information pertaining to criminal proceedings as information the public has a right to know, as, in such situations, the previous behaviour of the individual concerned implies the possibility of violating his or her right to private life. ${ }^{46}$

Furthermore, the balancing standard of the court also takes into account the manner and form of making the respective piece of information available to the public. The manner of making information public is not easy to track in an online environment, as the logic applied by search engine algorithms to connect pieces of information make this task almost impossible. Moreover, the first few hits published on the list of search results of a search engine may be relevant, as those hits are capable of causing the most significant damages to an individual. For this reason, ranking is another aspect the court may need to take into account

\footnotetext{
${ }^{43}$ Parliamentary Assembly, Resolution 1165 (1998).

${ }^{44}$ See Fressoz and Roire v. France (1999).

${ }^{45}$ See Axel Springer AG v. Germany (2012).

${ }^{46}$ Mosley v. United Kingdom [2012] at 112.
} 
in the future. ${ }^{47}$ Another solution could be if search engines made available other opinions as well, for example by acknowledging a right to respond. However, experience has shown that even if responding to information is made possible, "responses" to an article concerned are usually not displayed on the first hit page, casting a shadow of doubt over the efficiency of such a solution. In conclusion, the question of whether or not the respective piece of communication was published on one of the first hit pages should be taken into account.

In the course of balancing the right to respect for private life and the freedom of expression, the ECtHR also takes into account the manner in which the given piece of information was acquired. In the case law of the court, the consent of the individual concerned serves as due ground for publication, as noted above. The mere fact that a piece of information was obtained unlawfully does not render its use unlawful in and of itself, and does not imply that it must be removed from the public domain. In conclusion, it seems likely that, in the future, the focus of the ECtHR case law will shift from the issue of whether or not a piece of information is made available to others through the activities of a search engine to the matter of whether or not a given piece of information is of public interest. The latter factor may justify the circumstances of collecting the respective piece of information, as well as the assessment criteria pertaining to the right to be forgotten.

\section{Recommendations Regarding the Assessment Criteria pertaining to the Right to be Forgotten}

We are living in a world of Google. This means that we do not need to visit a library to copy books, because countless books are made available by Google in their entirety. However, Google also interlinks data provided to it by its users while they surf the Internet, and makes information generated through such interlinking universally available to other persons. Thus, Google has an obvious and significant role in deciding on what is presented to a user, what news are users informed about, and what content is made available to users. Google has a role in how the available information can shape the personality of users, and it can also infringe the personality rights of its users. ${ }^{48}$ For this reason and as discussed above, making pieces of information inaccessible might constitute an important means of protection the personality of individuals, and, considering that the shaping of opinions and beliefs of users is at stake, it might be necessary to introduce special objective requirements to facilitate the making of decisions concerning the legality of such "forgetfulness". The examination of the source of publication of the information to be forgotten might serve as such a factor. For example, pieces of information that are clearly relevant to journalistic activities should not be forgotten, and books and academic articles should not be rendered inaccessible. Furthermore, the right to be forgotten should not be applied in the context of information published by an official authority online.

\footnotetext{
${ }^{47}$ Guillemin (2015) at 234

${ }^{48}$ Prins (2014) at 2763.
} 
Another relevant factor could be the time element, ${ }^{49}$ which is based on the idea that information becomes irrelevant after a certain time, as the interest in having access to the information keeps reducing over time. Rolf Weber distinguishes between a right to forget and a right to be forgotten. The former is related to a past event, while the latter is not subject to any time related requirement, as it may be exercised by the data owner at any time. ${ }^{50}$ The court could also take into consideration this factor in the course of assessing the issue of the right to be forgotten. According to Google Advisory Council, certain kinds of information will be always available, such as information on crimes against humanity, because there is a public interest in keeping such information available without taking into account the lapse of time. However, there are rules that enable the perpetrators of crimes to start again with a "clean slate" after some period of time..$^{51}$ For example, a juvenile delinquent is normally exempted from the consequences of having a criminal record after some time, provided that certain other conditions are met. However, such crime related information cannot be erased without the introduction of these rules. ${ }^{52}$

It seems that the acknowledging the relevance of time can facilitate the identification of certain objective factors pertaining to the right to be forgotten. However, it should be noted that erasing such information without adopting a national regulatory framework first seems ill-advised. The direct applicability of the GDPR will mean the adoption of such national rules and the consolidation of European legislation on this field. However, the actual application of the right to be forgotten will show what other conditions need to be met to be able to decide on individual cases of exercising the right to be forgotten and to enable the courts of law to assess such cases on the basis of objective criteria. The criteria suggested above have been elaborated in pieces of legal literature and might be worthy of being taken into account by the ECtHR in future cases.

\section{Conclusions and Findings}

The right to be forgotten enables data subjects to cut links to pieces of information published online, while the information itself remains accessible. A most important problem with recognising this right as a human right as part of the right to private life seems that it may limit the freedom of expression on online surfaces, as well as the right of the public to access information. ${ }^{53}$ The acknowledgement of this issue, when taken in combination with other relevant factors, might shift the balance toward a more powerful approach regarding the acknowledgement of the right to private life. The problems arising from the operations of the Internet, and the relationship between technology and human

\footnotetext{
${ }^{49}$ Husovec (2014).

${ }^{50}$ Weber (2011) at 120.

${ }^{51}$ VOSS.\& Castets-Renard (2016).

${ }^{52} \mathrm{https} / / /$ static.googleusercontent.com/media/archive.google.com/hu/advisorycouncil/advisement/ad visory-report.pdf

${ }^{53}$ See, for example, Neville (2017).
} 
rights are far more complex. There is a wide gap between technical development and its legal implementations procedure, as legislation and the case law of courts is unable to keep up with the pace of digital progress without a significant delay. Furthermore, a seemingly emerging trend can simply become outdated overnight. ${ }^{54}$ Nonetheless, it seems clear that mass publicity driven by the consumption of news has overcome the existing barriers between private life and the public sphere, and this change compelled legislatures and courts of law to re-consider the foundations of existing rules and legislation. ${ }^{55}$ It seems that the new emerging social structure enabled virtual publicity to blur the traditional distinction between areas of public and private life more efficiently than it happened ever before. ${ }^{56}$

This paper made an attempt to outline some challenges regarding the interpretation of the right to be forgotten as reflected in the case law of the European Court of Human Rights and in comparison to the reasons presented by the Court of Justice of the European Union in its Google Spain decision. As pointed out above, the Google Spain decision failed to elaborate an accurate definition for the right to be forgotten, and it is also inconsistent with principles enshrined in the case law of the ECtHR, which plays a fundamental role in defining minimum European requirements. Thus, it may lead to uncertainties regarding the interpretation of European legal systems. ${ }^{57}$ Legal literature also fails to overcome such uncertainties, as the number of papers discussing the roots of the right to be forgotten in ECtHR case law is rather limited, even though the interpretation of the Charter of Fundamental Rights invoked in the Google Spain decision is supported by the ECtHR case law. Further inquiry into that case law would contribute to the scientific assessment of such matters. The directly applicable GDPR may bring about some clarity regarding the European understanding of the right to be forgotten, but it seems unclear how the interpretation of the difficulties arising from the application of the Regulation could be accommodated by the jurisdiction and case law of the ECtHR. In light of its current case law, it seems that the European Court of Human Rights is in favour of the enforcement of a right to remember, and it appears somewhat reluctant to generally enforce the right to be forgotten in the online realm.

\section{References}

ARTICLE 19's (2014). 'Response to Google's Advisory Council 16 October 2014.' at https://www.article19.org/data/files/medialibrary/37733/A19-comments-onRTBF.pdf

Barendt, E. (2010). 'A kifejezés szabadságának és a magánszféra védelmének egyensúlya a strasbourgi bíróság ítélkezési gyakorlatában' in Iustum Aequum Salutare 6(3):48.

\footnotetext{
${ }^{54}$ Coccoli (2017) at 224.

${ }^{55}$ Post (2017) at 756.

${ }^{56}$ Editorial Board of Pravoye Delo and Shtekel v Ukraine (2011).

${ }^{57}$ Frantziou (2014).
} 
Coccoli, J. (2017). 'The Challenges of New Technologies in the Implementsting of Human Rights: an Analysis of Some Critical Issues in the Digital Era in Peace Human Rights Governance 1(2):223-250.

Dulong de Rosnay, M. \& A. Guadamuz (2017). 'Memory Hole or Right to Delist? Implications of the Right to be Forgotten for Web Archiving' in Reset. Recherches en sciences sociales sur Internet [on line], $\mathrm{n}^{\mathrm{o}} 6$. http://journals.openedition.org/reset/ 807; DOI : $10.4000 /$ reset. 807

Frantziou, E. (2014). 'Further Developments in the Right to be Forgotten: The European Court of Justice's Judgment in Case C-131/12, Google Spain, SL, Google Inc v Agencia Espanola de Proteccion de Datos' in Human Rights Law Review 14(4):761777.

Feinberg, J. (1984). Harm to Others. New York: Oxford University Press.

Guillemin, G. (2015). 'The Right to be Forgotten: Whose Amnesia?' in J. Casadevall et al (eds.) Essays in Honour of Dean Spielmann. Oisterwijk: Wolf Legal Publishers, 229235

Hirschleifer, J. (1980). 'Privacy Its Origin, Function and Future' in Journal of Legal Studies 9(4):649-664.

Husovec, M. (2014). 'Should We Centralize the Right To Be forgotten Clearing House? at http://cyberlaw.stanford.edu/blog/2014/05/should-we-centralize-right-be-forgottenclearing-house

Iglezakis, I. (2016). 'The Right to be Forgotten: A New Digital Right for Cyberspace'. Paper presented at Segurança da informação e Direito Constitucional do ciberespaço, 17-18 November 2016, Lisbon at http://iglezakis.gr/2016/12/26/the-right-to-beforgotten-a-new-digital-right-for-cyberspace/

Keller, D. (2015). 'The Final Draft of Europe's 'Right to Be Forgotten' Law' at http:// cyberlaw.stanford.edu/blog/2015/12/final-draft-europes-right-be-forgotten-law.

Keller, P. (2014). Európai és nemzetközi médiajog - Liberális demokrácia, kereskedelem és az új média. Budapest: Complex, 395.

Koltay, A. (2017). 'Az internetes kapuőrök és az Emberi Jogok Európai Egyezményének 10. Cikke - A Sajtószabadság új Alanyai' in Állam- és Jogtudomány, 4:129-140.

Neville, A. (2017). 'Is it a Human Right to be Forgotten? Conceptualizing the World View; in Santa Clara J. Int'l L. 15:157-172.

Prins, J.E.J. (2014). 'Digitale Referenties' in Netherlands Juristenblad, 89(39): 2763.

Pérez, J. \& E. Baldía (coordinators) (2012). The debate on privacy and security over the network; Regulation and Markets, at www.publicpolicy.telefonica.com/es/ blogs/wp-content/uploads/2011/01/net_privacy.pdf

Post, C. R. (2017). 'Hírek a hálón: A Google Spain, az elfeledéshezvaló jog és a személyes adatok' in A. Koltay - B. Török (eds.) A szólásszabadság amerikai hagyományának magyarázata. Budapest: Wolters Kluwer, 702-790.

Sloot, B. (2018). 'Privacy as Personality Right: Why the ECtHR's focus on ulterior interests might prove indispensable in the Age of Big Data' in Utrecht Journal of International and European Law, 31(80): 25-50.

Solove, D. (2014). 'What Google Must Forget: The EU Ruling on the Right to Be Forgotten' at https://www.linkedin.com/pulse/20140513230300-2259773-whatgoogle-must-forget-the-eu-ruling-on-the-right-to-be-forgotten

Voss, W.G. \& C. Castets-Renard (2016). 'Proposal for an International Taxanomy on the Various Form on the Right to Be Forgotten. A study on the convergence norms' in Colo. Tech. L.J. 14(2):281-343.

Weber, R.H. (2011). 'The Right to be Forgotten: More than a Pandora's box?' in Journal of Intellectual Property, Information Technology and E-Commerce 2:120-130. 
Wechsler, S. (2015). 'The Right to remember: The European Conventionon Human Rights and the Right to be Forgotten' in 49 Colum. J.L. \& Soc. Probs. 49(1): 135165 .

\section{Cases}

Animal Defenders International v United Kingdom [2013] ECHR 362

Axel Springer AG v. Germany (Application No.39954/08. Judgement 7 February 2012)

Couderc and Hachette Filipachi Associesies v France (Application no. 40454/07. Judgement 10 November 2015 )

Editorial Board of Pravoye Delo and Shtekel v Ukraine (Application no 33014/05. Judgement of 5 May 2011)

Einarsson v. Iceland (Application no. 24703/15.Judgement 7 November 2017)

Erményi v Hungary (Application no. 22254/14. Judgment. 22 November 2016)

Fressoz and Roire v. France (Application no. 29183/95. Judgment 21 January 1999)

Google Spain SL, Google Inc. v Agencia Española de Protección de Datos, Mario Costeja González (2014) (C-131/12), ECLI:EU:C:2014:317.

Leander v. Sweden, 116 Ezr. Ct. H. R. (ser. A) 74 (1987).

Lingens v Austria (1986) 8 EHRR 407, 9815/82 [1986] ECHR 7.

Magyarországi Tartalomszolgáltatók Egyesülete and Index Zrt v Hungary [2016] ECHR 135. (Application No. 22947/13) [2016] ECHR 135J. Judgement 2 February 2016 at 56.

Mosley v United Kingdom [2011] 53 E.H.R.R. 30 (Judgement 10 May 2011)

Mosley $v$ United Kingdom (Application no. 48009/08; [2012] EMLR 1) Judgment 10 May 2011 at 112.

Palomo Sanchez and Others v. Spain [GC] 2011-V Eur. Ct. H.R. 187.

Tamiz v UK Application (Application no. 3877/14.Judgement 12 October 2017)

Times Newspapers Ltd (Nos. 1 And 2) v. The United Kingdom (Applications 3002/03 and 23676/03).

Von Hannover v. Germany (no. 2) Applications nos. 40660/08 and 60641/08. 7 February 2012, 108-113.

Wegrzynowski and Smolczewski v Poland (Application No.33846/07. Judgment 16 July 2013)

\section{Instruments}

Parliamentary Assembly, Resolution 1165 (1998), Right to privacy

Convention for the Protection of Human Rights and Fundamental Freedoms art. 1. Nov. 4, 1950, 231, U. N. T. S. 222.

Directive 95/46/EC of the European Parliament and of the Council of 24 October 1995 on the protection of individuals with regard to the processing of personal data and on the free movement of such data.

Regulation (EU) 2016/679 of the European Parliament and Of the Council. The EU General Data Protection Regulation (“GDPR") 